\title{
The Contrasting Responses of Mycorrhizal Fungal Mycelium Associated with Woody Plants to Multiple Environmental Factors
}

\author{
Cunguo Wang ${ }^{1}\left(\mathbb{D}\right.$, Shengwei Zong ${ }^{1, *}$ and Mai-He Li ${ }^{1,2}(\mathbb{D}$ \\ 1 Key Laboratory of Geographical Processes and Ecological Security in Changbai Mountains, Ministry of \\ Education, Northeast Normal University, Changchun 130024, China; wangcg505@nenu.edu.cn (C.W.); \\ maihe.li@wsl.ch (M.-H.L.) \\ 2 Swiss Federal Research Institute WSL, Zuercherstrasse 111, CH-8903 Birmensdorf, Switzerland \\ * Correspondence: zongsw049@nenu.edu.cn; Tel.: +0431-85099550
}

Received: 2 September 2019; Accepted: 31 October 2019; Published: 4 November 2019

\begin{abstract}
Research Highlights: Extraradical mycorrhizal fungal mycelium (MFM) plays critical roles in nutrient absorption and carbon cycling in forest ecosystems. However, it is often ignored or treated as a root uptake apparatus in existing biogeochemical models. Methods: We conducted a meta-analysis to reveal how MFM responds to various, coinciding environmental factors and their interactions. Results: Nitrogen (N) addition and N-phosphorus (P)-potassium (K) combination significantly decreased MFM. However, elevated $\mathrm{CO}_{2}$, organic matter addition, $\mathrm{P}$ addition, and $\mathrm{CO}_{2}-\mathrm{N}$ combination significantly increased MFM. In contrast, warming, K addition, N-P combination, and P-K combination did not affect MFM. Mycorrhizal fungal levels (individual vs. community), mycorrhizal type (ectomycorrhizal fungi vs. arbuscular mycorrhizal fungi), treatment time ( $<1$ year vs. $>1$ year), and mycelium estimation/sampling method (biomarker vs. non-biomarker; ingrowth mesh bag vs. soil core) significantly affected the responses of MFM to elevated $\mathrm{CO}_{2}$ and $\mathrm{N}$ addition. The effect sizes of $\mathrm{N}$ addition significantly increased with mean annual precipitation, but decreased with soil $\mathrm{pH}$ and host tree age. The effect sizes of $\mathrm{P}$ addition significantly increased with $\mathrm{N}$ concentration in host plant leaves. Conclusions: The differential responses revealed emphasize the importance of incorporating MFM in existing biogeochemical models to precisely assess and predict the impacts of global changes on forest ecosystem functions.
\end{abstract}

Keywords: carbon allocation; global change; mycorrhizal fungal community; mycorrhizal fungal mycelium; nitrogen addition

\section{Introduction}

Globally, mycorrhizal symbioses are common and extensive in terrestrial vegetation [1], and play a key role in biogeochemical cycles of forest ecosystems [2-4]. Mycorrhizal fungi transfer nutrients directly to their host plants in exchange for photosynthetically derived carbon [5]. Extraradical mycorrhizal fungal mycelium (MFM), which had been traditionally ignored in field assessments, constitutes the vast majority (about $60 \%-95 \%$ for ectomycorrhizas, EM) of the total mycorrhizal fungal biomass, while the Hartig net, mantle, and sporocarps constitute $5 \%-40 \%$ only [6]. In terms of root foraging, MFM of EM may permit a more thorough exploitation of soil mineral and organic nutrients [1,7]. In terms of absorptive efficiency, MFM of EM and arbuscular mycorrhizas (AM) is clearly more effective for obtaining greater absorption area per unit of carbon allocated to the mycelium than to the root [8]. Therefore, mycorrhizal fungi can greatly enhance the nutrient absorption capacity of the plant root system [9]. For instance, some EM fungi are known to colonize organic matter, wood ash, and leaf litter by forming a dense mycelium [5,7], and to acquire nutrients from organic 
matter in the soil [10]. MFM of EM and AM accounts for $10 \%-50 \%$ of the belowground allocated carbon [11,12]. Furthermore, about $50 \%-62 \%$ of the soil organic carbon pool may be a result of fungal residues remaining in the soil after the death of the mycelium of EM [13]. This probably exceeds the input via aboveground leaf litter and belowground fine root turnover [14,15]. Overall, MFM plays an important role in the mobilization and acquisition of nutrients from the soil, and is intimately involved in the sequestration and partitioning of carbon into the soil $[16,17]$.

Multiple important aspects of the global environment greatly influence functioning of mycorrhizal plants and their fungal associates with potential implications for forest ecosystem carbon cycling [18,19]. The atmospheric concentration of $\mathrm{CO}_{2}$ is predicted to reach 550 ppm by 2100, and is likely to be accompanied by an increase in global average annual temperature of as much as $4.4 \pm 0.5{ }^{\circ} \mathrm{C}$ for the period 2070-2099 [20]. More carbon is likely to be allocated to tree root systems under future elevated $\mathrm{CO}_{2}$ scenarios, leading to increased belowground forest productivity [21]. An eventual consequence may be increased carbon availability to fungi for the development of the mycorrhizal mycelium [8]. Moreover, temperature is a key factor that regulates the growth and metabolic activity of mycorrhizal fungi [22]. For example, AM colonization intensity is tightly related to the temperature on the global scale, with peak colonization under warm temperature during growing season [22]. In a climate-changing world, changes in both atmospheric $\mathrm{CO}_{2}$ concentration and temperature will influence mycorrhizal fungi and their host plant at various scales [23]. Yet, we have no information about whether relationships of MFM with temperature at the global scale are the same as those at smaller scales. As a result of greenhouse gas-induced global warming, wildfires may deeply influence soil organic carbon dynamics through heating and wildfire-deposited charcoal [24], leading to dramatic changes in soil physicochemical properties and microbial activity [25]. On the other hand, the addition of organic matter or wood ash is a common forest management practice to improve soil nutrient availability and soil structure [26]. In both laboratory and field experiments, the application of organic matter or wood ash stimulates the growth of certain EM fungi [27,28]. Colonization of mycorrhizal mycelium can enhance opportunities to acquire nutrients from the organic matter and wood ash [29]. However, we know little about mechanisms underlying the colonization of organic matter or wood ash by some mycorrhizal fungi [7].

There is an increasing interest in mycorrhizal fungal behavior to elevated atmospheric nitrogen (N) deposition, another major driver of global change. It is reported that $\mathrm{N}$ fertilization may negatively impact the respiration of MFM, leading to a reduced flux of plant-derived carbon back to the atmosphere via mycorrhizal fungi [30]. N addition, on the one hand, may decrease MFM amount, and may also lead to changes in the growth of MFM and the composition of the fungus community [31]. On the other hand, any extrinsic factors (e.g., $\mathrm{N}$ fertilization) that influence host plant's carbon production, belowground carbon allocation, and thus the carbon availability will affect the MFM, since mycorrhizal fungi are fed by carbon from their host plants [21]. The host plants allocate less carbon to mycorrhizal symbionts and thus limit the mycorrhizal growth in the case of insufficient nutrient supply [32]. The two most common groups of mycorrhizas, EM and AM fungi, employ different nutrient acquisition and carbon utilization strategies $[33,34]$, thus, factors influencing the intrinsic properties of mycorrhizal fungal carbon utilization can also bring about large variations of MFM [18,35]. Hence, one of the significant challenges to ecologists is to realize how mycorrhizal fungi respond to the various, coinciding environmental factors and their interactions. In addition, phosphorus $(\mathrm{P})$ is known to accumulate in the fungal mantle of mycorrhizal roots when supplied in excess amounts, but this P resource stored will rapidly be transferred to the host under conditions of low P availability [36]. However, we still lack the information about the impact of altered $P$ availability on the growth of MFM, especially during the early stages of fungal development, in most forest ecosystems [37,38].

The external mycorrhizal mycelium, as the most dynamic component of the mycorrhizal symbiosis, is likely to be the fastest indicator of how mycorrhizal fungi react to the wide variation in environments $[39,40]$. A number of methods have been developed to collect (e.g., ingrowth mesh bag, soil core, etc.) and quantify (e.g., biomarker, visual method, etc.) the production and standing biomass 
of MFM (Table 1). However, the strengths and weaknesses of the currently applied methods also potentially influence the accuracy of estimation of MFM [17]. At present, we know that MFM is critical in precisely assessing and predicting the responses of forest ecosystem carbon flow and nutrient cycle dynamics to global climate change. However, the majority of previous meta-analyses mainly focus on the responses of mycorrhizal abundance, root colonization, mycorrhizal composition, and mycorrhizal activity to global change $[18,41]$. Consequently, we still lack a thorough understanding in the direction and size of MFM responses to multiple environmental factors. Here, we present a meta-analysis on the effects and effect range of multiple environmental factors on the MFM. Separate meta-analyses were conducted for elevated $\mathrm{CO}_{2}, \mathrm{~N}$ addition, $\mathrm{P}$ addition, $\mathrm{K}$ addition, organic matter addition, warming, $\mathrm{CO}_{2}-\mathrm{N}$ combination, N-P combination, P-K combination, and N-P-K combination. Our hypothesis is that MFM positively responds to $\mathrm{CO}_{2}$, organic matter, and warming, but it negatively responds to N, P, and K availability. We aimed to answer the questions of (a) how MFM responds to multiple environmental factors and their combination, and (b) how mycorrhizal hierarchical and experimental aspects affect the responses of MFM to different environmental factors.

Table 1. Mycorrhizal fungal mycelium (MFM) estimation methods and experimental treatment settings in this meta-analysis.

\begin{tabular}{|c|c|c|}
\hline \multicolumn{3}{|c|}{ Mycorrhizal Fungal Mycelium Estimation Methods and Treatment Settings } \\
\hline Estimation methods & & Measurement index \\
\hline Biomarker & Chitin; ergosterol; glomalin; PLFA 16: 1w5c; PLFA 18: $2 \omega 6,9$ & Fungal mycelium biomass \\
\hline Non-biomarker & $\begin{array}{l}\text { Agar film; fan-like manner; gridline intersection; } \\
\text { membrane-filter }\end{array}$ & Fungal mycelium length \\
\hline \multicolumn{3}{|c|}{ Experimental treatment settings } \\
\hline Organic matter addition & Compost; litter; organic fertilizer; wood ash & \\
\hline Elevated $\mathrm{CO}_{2}$ & $\begin{array}{l}\text { Experimental soil plant atmosphere system; free air } \mathrm{CO}_{2} \\
\text { enrichment (FACE); microcosm; open top chamber (OTC) }\end{array}$ & \\
\hline Nitrogen $(\mathrm{N})$ addition & Ammonium nitrate; ammonium sulfate; sodium nitrate; urea & \\
\hline Phosphorus $(\mathrm{P})$ addition & $\begin{array}{l}\text { Apatitle; sodium dihydrogen phosphate; superphosphate; } \\
\text { triple superphosphate }\end{array}$ & \\
\hline Potassium $(\mathrm{K})$ addition & Biotite; Osmocote & \\
\hline Warming & Greenhouse; heating cable; infrared heating & \\
\hline
\end{tabular}

\section{Materials and Methods}

\subsection{Data Collection}

We searched published peer-reviewed papers using Web of Science, Google Scholar, China National Knowledge Infrastructure and VIP Information Network (the list of the data sources shown in Appendix A). The key words used were mycorrhizal fungal mycelium, extrametrical/external mycelium/hyphae, fungal mycelia, mycorrhizal fungi, mycorrhizal fungal growth, belowground responses, elevated $\mathrm{CO}_{2}$ /atmospheric carbon dioxide, atmospheric $\mathrm{CO}_{2}$ enrichment, nitrogen/phosphorus/potassium addition/deposition/fertilization/amendment/availability, warming, temperature manipulation, wood ash/organic matter/compost addition, woody plant/tree/shrub (Table 1). Different combinations of these words connected with AND or OR were repeatedly used to find publications. Only published woody (trees, shrubs) plant-related studies satisfying all the following criteria were selected for the present meta-analysis: (a) studies with control and treatment under the same abiotic and biotic conditions; (b) the means, standard errors/standard deviations, and sample sizes were reported; (c) both field manipulation studies and laboratory incubation studies were selected; (d) MFM was estimated by biomarker (such as ergosterol, phospholipid fatty acid, etc. for measuring the biomass of MFM) and non-biomarker (such as gridline 
intersection, agar film, etc. for measuring the length of MFM) analysis from ingrowth mesh bag and soil core methods (Table 1). If a particular study reported data from several mycorrhizal fungal species or host plant species, they were considered as independent data points. When parameters were measured several times in a study, only the last sampling date was used for our meta-analysis. We identified a total of 53 studies (the list of the data sources can be found in the Appendix A), which yielded 46 observations for elevated $\mathrm{CO}_{2}, 11$ for $\mathrm{K}$ addition, 37 for $\mathrm{N}$ addition, 23 for organic matter addition, 30 for $\mathrm{P}$ addition, 12 for warming, six for $\mathrm{CO}_{2}-\mathrm{N}$ combination, 18 for N-P combination, eight for P-K combination, and 14 for N-P-K combination.

Data collection consisted of obtaining the means of the experimental and control group with their standard deviations (SD) and replicate numbers (N). Standard errors (SE) were transformed to SD according to the equation of $\mathrm{SD}=\mathrm{SE} \times \operatorname{sqrt}(\mathrm{N})$. As the calculated response ratio is dimensionless, the units of parameters were not considered. When graphical data was presented in a paper, values were extracted from figures using GetData Graph Digitizer 2.24 (http://getdata-graph-digitizer.com). We also recorded data on experimental settings (such as field site location, experiment date, sampling method, experimental levels, and treatment duration), biotic factors (such as tree age, leaf nutrient content, and mycorrhizal type), climatic factors (such as mean annual temperature, mean annual precipitation) and edaphic factors (such as soil carbon/nitrogen ratio and $\mathrm{pH}$ ).

\subsection{Meta-Analysis}

We selected the natural log-transformed response ratio (LRR) to calculate the "effect size" of different global change factors on MFM [42]. We defined LRR as the ratio of the value of a parameter in the treatment group to that in the control group. Confidence intervals (CI) of the effect size were generated using bootstrapping [43]. The treatment effects of global change factors were considered to be significant if the $95 \%$ confidence interval of LRR did not overlap with zero [43]. We implemented hierarchical mixed effects meta-analyses using the rma.mv function in the package metaphor 2.10, which allows the specification of nesting groups [44]. Hierarchical mixed effects meta-analyses include fixed and random effects to account for differences across studies [45]. The mixed effects model was used to analyze the effects of elevated $\mathrm{CO}_{2}$ on $\mathrm{MFM}$, with mycorrhizal fungal level (individual vs. community), mycorrhizal type (EM vs. AM), duration time of elevated $\mathrm{CO}_{2}$ treatment ( $<1$ year vs. $>1$ year), and MFM estimation method (biomarkers vs. non-biomarker) as main fixed factors. The mixed effects model was used to detect the effects of $\mathrm{N}$ addition on MFM, with sampling method (ingrowth vs. soil core), mycorrhizal type (EM vs. AM), incubation time of ingrowth method ( $<1$ year vs. $>1$ year), and MFM estimation method (biomarkers vs. non-biomarker) as main fixed factors. For all mixed effects, we included study identity as a random effect to account for multiple cases coming from the same study. Host phylogeny strongly affects the plant-mycorrhizal fungus systems, it explains $75 \%$ and $20 \%$ of the variations in fungal species richness and community composition, respectively [46]. Thus, host plant phylogeny was conducted as a correlation matrix derived from the phylomatic tree (http://phylodiversity.net/phylomatic/pmws) to control for similarities [47]. We transformed phylomatic tree to the correlation matrix using the $v c v$ function in the package ape 5.0 [48], except for studies or data in relation to $\mathrm{K}$ addition and $\mathrm{P}-\mathrm{K}$ combination treatments due to few host plant species studied. In the Results section, we report the total heterogeneity in effect sizes $\left(Q_{t}\right)$ among studies and the difference among group cumulative effect sizes $\left(Q_{m}\right)$.

\section{Results}

\subsection{Effects of Elevated $\mathrm{CO}_{2}$ on Mycorrhizal Fungal Mycelium}

The hierarchical mixed effects meta-analyses showed that woody plants' MFM significantly increased under elevated $\mathrm{CO}_{2}\left(Q_{\mathrm{t}}=441.26, p<0.001\right)$ (Figure 1$)$. We found that the positive responses of MFM to elevated $\mathrm{CO}_{2}$ were significantly affected by mycorrhizal fungal level (individual vs. community), mycorrhizal type (EM vs. AM), duration time of elevated $\mathrm{CO}_{2}(<1$ year vs. $>1$ year), 
and mycelium estimation method (biomarker vs. non-biomarker) (Figure 2). Specifically, MFM at the individual level, EM fungal mycelium, MFM from experiments of $<1$ year, and MFM derived from non-biomarker method significantly increased under elevated $\mathrm{CO}_{2}$ (Figure 2). By contrast, MFM at the community level, AM fungal mycelium, MFM from experiments of $>1$ year, and MFM estimated from biomarker were not altered by elevated $\mathrm{CO}_{2}$ (Figure 2).

\subsection{Effects of $N$ Addition on Mycorrhizal Fungal Mycelium}

Our meta-analysis showed that $\mathrm{N}$ addition $\left(Q_{\mathrm{t}}=146.20, p<0.001\right)$ significantly decreased MFM. However, we found that $\mathrm{CO}_{2}-\mathrm{N}$ combination significantly increased MFM $\left(Q_{\mathrm{t}}=10.72, p=0.06\right)$ (Figure 1). The negative responses of MFM to $\mathrm{N}$ addition were significantly affected by sampling method (ingrowth mesh bag vs. soil core), mycorrhizal type (EM vs. AM), incubation time of ingrowth mesh bag ( $<1$ year vs. $>1$ year), and mycelium estimation method (biomarker vs. non-biomarker) (Figure 3). Specifically, MFM from ingrowth mesh bag, EM fungal mycelium, MFM from incubation time of ingrowth mesh bag $<1$ year, and MFM estimated from biomarkers significantly decreased under $\mathrm{N}$ addition (Figure 3). In comparison, MFM from soil core, AM fungal mycelium, MFM from incubation time of ingrowth mesh bag $>1$ year, and MFM estimated from non-biomarker were unchanged under $\mathrm{N}$ addition (Figure 3). Furthermore, we found that the effect sizes of $\mathrm{N}$ addition on MFM increased with mean annual precipitation $\left(Q_{\mathrm{m}}=8.98, p<0.01\right)$ but it decreased with soil $\mathrm{pH}\left(Q_{\mathrm{m}}=3.85, p<0.05\right)$ and host plant age $\left(Q_{\mathrm{m}}=5.09, p<0.05\right.$; Figure $\left.4 \mathrm{a}-\mathrm{c}\right)$. The effect size of $\mathrm{N}$ addition on MFM was not correlated with latitude of experimental site location $\left(Q_{\mathrm{m}}=2.40, p=0.12\right)$, mean annual temperature $\left(Q_{\mathrm{m}}=3.72, p=0.05\right)$, soil carbon/nitrogen ratio $\left(Q_{\mathrm{m}}=0.23, p=0.63\right), \mathrm{N}$ addition level $\left(Q_{\mathrm{m}}=3.84\right.$, $p=0.05)$, and sampling depth $\left(Q_{\mathrm{m}}=0.00, p=0.96\right)$.

\subsection{Effects of P Addition on Mycorrhizal Fungal Mycelium}

The mixed effects meta-analyses showed that MFM significantly increased in the P addition condition $\left(Q_{\mathrm{t}}=118.70, p<0.001\right)$ (Figure 1). The N-P combination $\left(Q_{\mathrm{t}}=157.79, p<0.001\right)$, and the P-K combination $\left(Q_{\mathrm{t}}=5.07, p=0.65\right)$ had no effects on MFM (Figure 1$)$, but the effect sizes of $P$ addition on MFM significantly increased with $\mathrm{N}$ content in host plant leaves $\left(Q_{\mathrm{m}}=4.73, p<0.05\right.$; Figure $\left.4 \mathrm{~d}\right)$. Moreover, the N-P-K combination $\left(Q_{\mathrm{t}}=182.89, p<0.001\right)$ significantly decreased MFM (Figure 1$)$. Mycorrhizal type $\left(Q_{\mathrm{m}}=27.25, p<0.001\right)$ significantly affected the positive responses of MFM to $\mathrm{P}$ addition, with increases for EM fungal mycelium (RR: 0.43 ; 95\% CI: 0.17-0.68) and for AM fungal mycelium (RR $=0.35 ; 95 \% \mathrm{CI}: 0.14-0.55)$. Moreover, the response of MFM to P addition was not influenced by host plant age $\left(Q_{\mathrm{m}}=1.02, p=0.31\right)$, latitude of experimental site location $\left(Q_{\mathrm{m}}=23.26\right.$, $p=0.06)$, sampling depth $\left(Q_{\mathrm{m}}=0.07, p=0.79\right)$, sampling method $\left(Q_{\mathrm{m}}=0.23, p=0.63\right)$, mean annual precipitation $\left(Q_{\mathrm{m}}=0.20, p=0.66\right)$, mean annual temperature $\left(Q_{\mathrm{m}}=0.25, p=0.62\right)$, P concentration in host plant leaves $\left(Q_{\mathrm{m}}=0.32, p=0.57\right)$, soil carbon/nitrogen ratio $\left(Q_{\mathrm{m}}=0.00, p=0.96\right)$, and soil $\mathrm{pH}$ $\left(Q_{\mathrm{m}}=0.23, p=0.64\right)$.

\subsection{Effects of Other Environmental Factors on Mycorrhizal Fungal Mycelium}

The results from the hierarchical mixed effects meta-analyses showed that MFM significantly increased under organic matter addition $\left(Q_{t}=1140.49, p<0.001\right)$. In contrast, warming $\left(Q_{t}=118.94\right.$, $p<0.001)$ and $\mathrm{K}$ addition $\left(Q_{\mathrm{t}}=16.61, p=0.08\right)$ had no effect on MFM (Figure 1). Unfortunately, however, there was not sufficient information available to determine the factors that influence the responses of MFM to organic matter addition, warming, and K addition (Figure 1). 


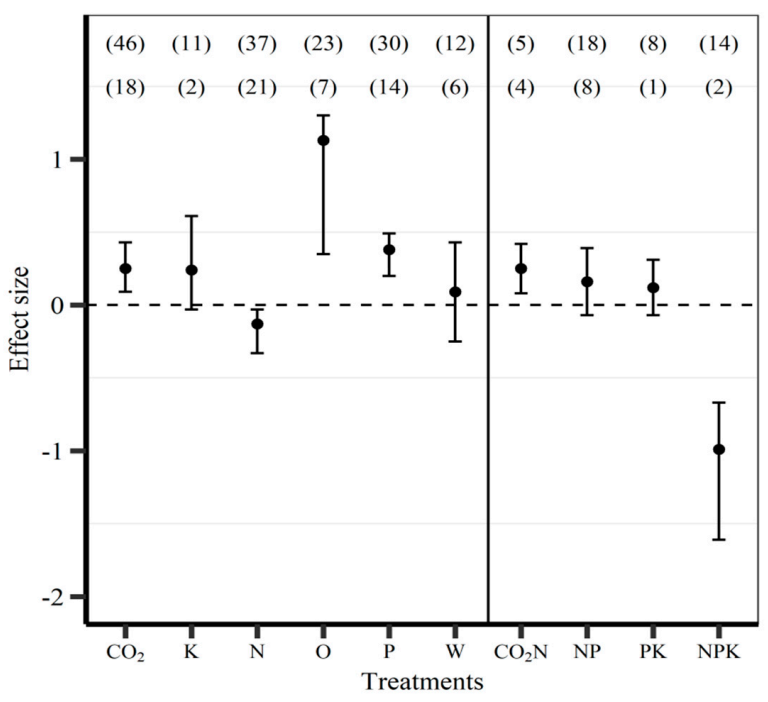

Figure 1. The mean effect size of different treatments on mycorrhizal fungal mycelium (MFM). Error bars represent $95 \%$ confidence intervals. The dashed line is drawn at a mean effect size $=0$. The effect of treatments is considered significant if the $95 \%$ confidence intervals of the effect size do not cover zero. Numbers given on the top indicate the numbers of cases (above) and studies (below) for each treatment. $\mathrm{CO}_{2}$, elevated $\mathrm{CO}_{2} ; \mathrm{K}$, potassium addition; $\mathrm{N}$, nitrogen addition; $\mathrm{O}$, organic matter addition; $\mathrm{P}$, phosphorus addition; $\mathrm{W}$, warming; $\mathrm{CO}_{2} \mathrm{~N}, \mathrm{CO}_{2}-\mathrm{N}$ combination; NP, N-P combination; PK, P-K combination; NPK, N-P-K combination.

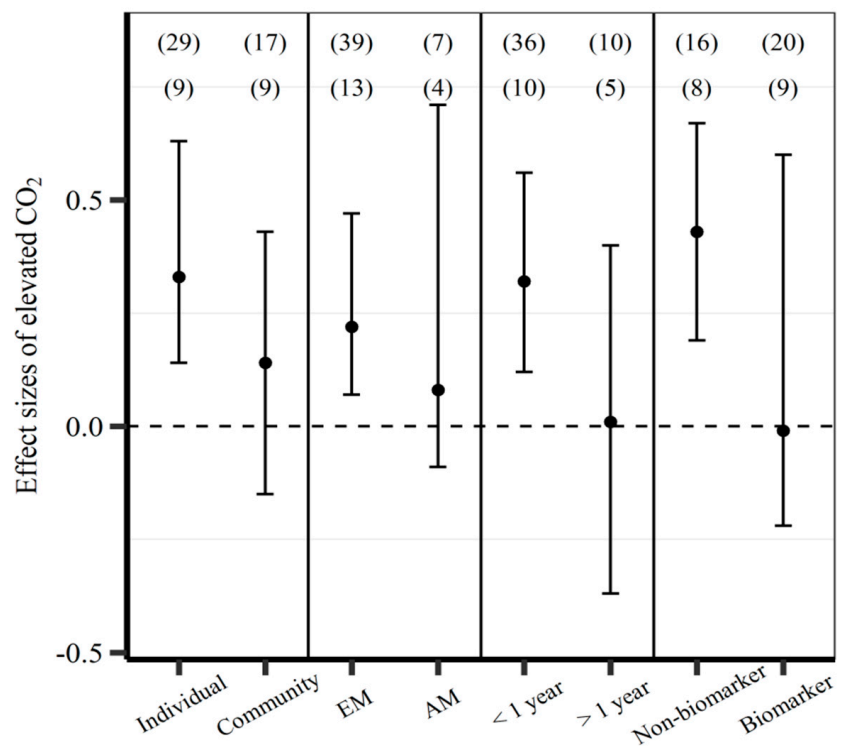

Figure 2. Mean effect size of elevated $\mathrm{CO}_{2}$ on mycorrhizal fungal mycelium (MFM), categorized into different groups according to mycorrhizal fungal level (individual vs. community), mycorrhizal type (ecomycorrhizal fungi, EM vs. arbuscular mycorrhizal fungi, AM), duration time of elevated $\mathrm{CO}_{2}$ treatment ( $<1$ year vs. $>1$ year), and MFM estimation method (biomarkers vs. non-biomarker). The dashed line is drawn at mean effect size $=0$. Error bars represent $95 \%$ confidence intervals. Numbers given on the top represent the numbers of cases (above) and studies (below). 


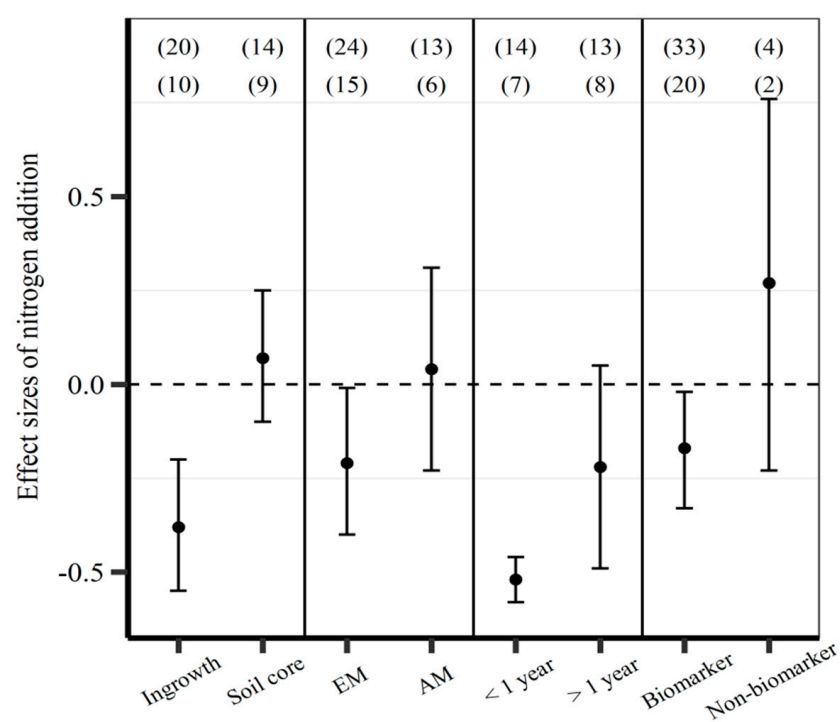

Figure 3. Mean effect size of nitrogen addition on mycorrhizal fungal mycelium (MFM), categorized into different groups according to sampling method (ingrowth vs. soil core), mycorrhizal type (EM vs. AM), incubation time of ingrowth method ( $<1$ year vs. $>1$ year) and MFM estimation method (biomarkers vs. non-biomarker). The dashed line is drawn at mean effect size $=0$. Error bars represent $95 \%$ confidence intervals. Numbers given on the top represent the numbers of cases (above) and studies (below).
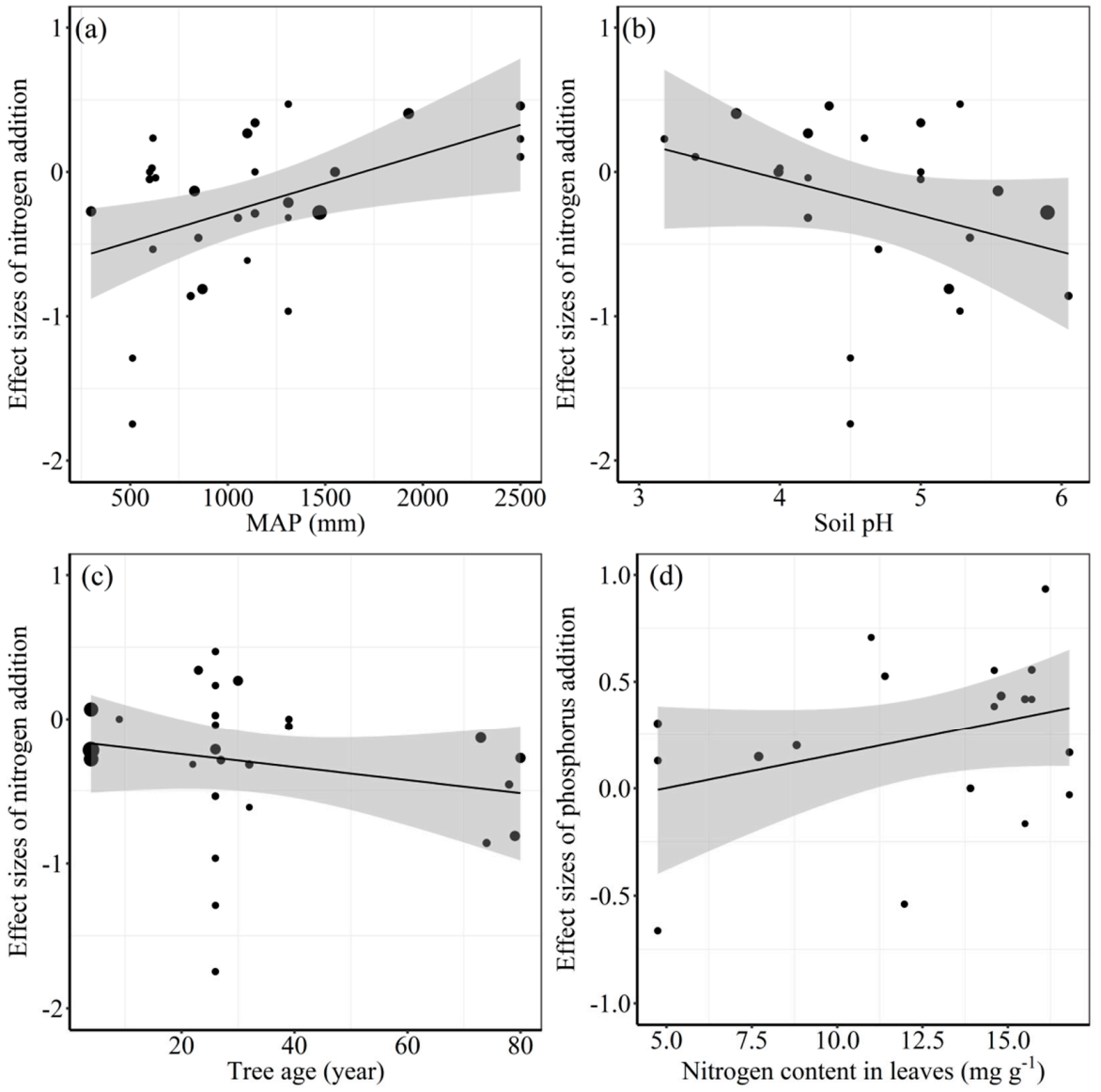

Figure 4. Relationships between effect size of nitrogen addition on mycorrhizal fungal mycelium (MFM) and mean annual precipitation (MAP, a), soil $\mathrm{pH}(\mathbf{b})$ and host plant age (c), and relationships between effect size of phosphorus addition on MFM and leaf nitrogen concentration in host plants (d). Grey bands indicate $95 \%$ confidence intervals. Sizes of dots indicate weights of observations. 


\section{Discussion}

Our present hierarchical mixed effects meta-analyses showed that MFM significantly increased under elevated $\mathrm{CO}_{2}$, organic matter addition, $\mathrm{P}$ addition, and $\mathrm{CO}_{2}-\mathrm{N}$ combination. However, $\mathrm{N}$ addition and the N-P-K combination significantly decreased MFM. In contrast, warming, K addition, the N-P combination, and the P-K combination had no effects on MFM. Mycorrhizal types (AM vs. EM), treatment time ( $<1$ year vs. $>1$ year), and sampling/estimation method (ingrowth mesh bag vs. soil core/biomarker vs. non-biomarker) significantly influenced the responses of MFM to elevated $\mathrm{CO}_{2}$ and $\mathrm{N}$ addition. The effect size of $\mathrm{N}$ addition was significantly positively correlated with mean annual precipitation, but negatively with soil $\mathrm{pH}$ and host tree age. The effect size of $\mathrm{P}$ addition significantly increased with $\mathrm{N}$ content in host plant leaves.

\subsection{The Responses of MFM to Elevated $\mathrm{CO}_{2}$}

We observed an increase in MFM under elevated $\mathrm{CO}_{2}$, which is in agreement with our hypothesis that $\mathrm{CO}_{2}$ had a significantly positive impact on the growth of mycorrhizal fungi. It is widely reported that elevated $\mathrm{CO}_{2}$ proportionally increases carbon allocation to tree roots [21,34,49], and a great deal of which will be ultimately transferred to the mycorrhizal fungi to form mycelium [8,21]. However, this positive effect appeared at the individual level of mycorrhizal fungi, but disappeared at the community level. This difference may result from intrinsic properties of the two mycorrhizal fungal levels such as differences in growth rate and types of mycelia and complex interactions among different mycorrhizal fungi [16]. The constantly luxurious supply of carbon delivered by the host plant under elevated $\mathrm{CO}_{2}$ causes a shift in mycorrhizal fungus species composition towards those with high metabolic activities and copious mycelium [50,51]. These shifts of mycorrhizal community structure and contrasting responses of different mycorrhizal fungal species will likely affect responses of MFM at community level to elevated $\mathrm{CO}_{2}$ [52], because some mycorrhizal fungal species are not sensitive to elevated $\mathrm{CO}_{2}[16,40,51]$. Moreover, the positive responses of MFM to elevated $\mathrm{CO}_{2}$ found during the first treatment year was not observed in the treatment duration group of $>1$ year, suggesting that the effect reduced with the prolonged experimental duration. It is considered that long-term exposure to elevated $\mathrm{CO}_{2}$ generally reduce the initial stimulation of photosynthesis in many plant species and even frequently suppresses photosynthesis [35]. Previous studies suggest that long-term elevated $\mathrm{CO}_{2}$ exposure leads to nutrient limitation such as $\mathrm{N}$ limitation [53]. Therefore, the positive growth response of MFM to elevated $\mathrm{CO}_{2}$ may be truncated by soil nitrogen limitations.

Our meta-analysis highlights that different mycorrhizal types (AM vs. EM) exhibited the contrasting responses of MFM to elevated $\mathrm{CO}_{2}$ and $\mathrm{N}$ addition. There is good evidence for greatly fundamental discrepancies between EM and AM symbioses in nutrient acquisition strategies and carbon storage properties [2]. It has been also observed that the growth patterns of EM symbioses differed from those of $\mathrm{AM}$ symbioses under elevated $\mathrm{CO}_{2}$ [35]. Moreover, EM plants can allocate more carbon to their fungal partner than AM plants [54,55]. Accordingly, EM symbioses contribute more to mycorrhizal fungal growth, while AM symbioses are more favorable to plant growth under elevated $\mathrm{CO}_{2}$ [35]. EM fungi are generally considered to be more sensitive to environmental factors than $\mathrm{AM}$ fungi $[56,57]$, which is proven by our results of the significantly positive effects of elevated $\mathrm{CO}_{2}$ and negative effects of $\mathrm{N}$ addition on MFM of EM. Here, we provide additional evidence that the relative dominance of EM or AM trees in a forest may partly determine the response pathways of carbon and $\mathrm{N}$ cycling to various global change factors. In contrast, we found the consistently positive effects of $\mathrm{P}$ addition on MFM of EM and AM. These results perhaps suggest the similar P utilization model, but contrasting $\mathrm{N}$ utilization models, between EM and AM fungi. However, our interpretation of these results is inevitably constrained by the fact that there are very few studies on AM fungi. Our analysis only included four and six studies on MFM of AM associated with woody plants under elevated $\mathrm{CO}_{2}$ and $\mathrm{N}$ addition, respectively. Clearly, more studies on responses of AM fungal mycelium to global change are required to illuminate whether this difference is caused by research bias or does reflect 
some underlying fundamental variations in either the biology of the mycorrhizal fungi or the host plants or the combination of both.

\subsection{The Responses of MFM to $N$ Addition}

The significant reduction of MFM after $\mathrm{N}$ addition observed may be attributed to a greater carbon demand for aboveground plant growth, leading to relatively less carbon being allocated belowground to support nutrient assimilation [30,31]. A meta-analysis covering 31 studies notes that mycorrhizal fungal colonization of fine root tips decreases by $15 \%$ under $N$ fertilization [41]. Plants adapt to elevated $\mathrm{N}$ input by weakening the associations with mycorrhizal fungi, suggesting that a higher proportion of $\mathrm{N}$ is taken up directly by plant roots [18]. Moreover, more carbon allocated to mycorrhizal fungi will be used for energy purposes and as carbon skeletons for amino acid assimilation in elevated $\mathrm{N}$ availability, consequently, less carbon will be available for mycorrhizal fungal growth [58]. It is well documented that a significant decline in ectomycorrhizal sporocarp production happens in forests subjected to elevated $\mathrm{N}$ deposition [6,7]. Additionally, the acidifying effect of $\mathrm{N}$ addition has also been found to inhibit mycorrhizal fungal activity, and thus negatively affecting mycelia growth [59]. Meanwhile, we observed significantly negative relationship between the effect size of $\mathrm{N}$ addition on MFM and soil $\mathrm{pH}$, indicating greater suppression of mycorrhizal fungi growth in lower $\mathrm{pH}$ soils. Acidity stress is likely to favor mycorrhizal fungus species with slow mycelia growth [60]. In addition to soil characteristics, climate has been considered as an important driver of the intimacy of the plant-fungi relationship at global scale [22]. Our results showed that the effect size of N addition on MFM was associated with mean annual precipitation. Perhaps enhanced $\mathrm{N}$ leaching/export induced by higher precipitation can relieve the inhibiting effects of $\mathrm{N}$ addition on the MFM [61]. Moreover, it is found that the greater precipitation has a positive effect on EM fungal production [6], while drought will prevent the growth of MFM [62]. The strong and contrasting influences of $\mathrm{N}$ and water availabilities on mycorrhizal fungi have crucial implications for carbon and nutrient cycling dynamics in forest ecosystems [6]. Hence, the influences of changes in precipitation on the responses of mycorrhizal fungi to increasing $\mathrm{N}$ deposition warrants further research.

We found opposite effects of elevated $\mathrm{CO}_{2}$ and $\mathrm{N}$ addition on MFM. This indicates that elevated $\mathrm{CO}_{2}$ and increased $\mathrm{N}$ input have opposite effects on the relative carbon allocation of plants to belowground parts. Thus, mycorrhizas in forest ecosystems are exposed to a paradoxical situation under multiple factor changes. Indeed, global change is not a single-factor phenomenon, so the strong and contrasting effects of multiple global change factors (i.e., elevated $\mathrm{CO}_{2}, \mathrm{~N}$ deposition and changed precipitation) on MFM have important implications for carbon flow and nutrient cycling dynamics in forest ecosystems [34]. For instance, multiple soil nutrients combine to regulate fine roots and thus the association with mycorrhizal fungi [63].

Tree-age-related variation in belowground carbon allocation is vital for comprehensive understanding of complex carbon cycling during stand development $[4,64]$. It is evident that effect size of $\mathrm{N}$ addition on MFM is negatively correlated with the host plant age. Higher rates of mycorrhizal mycelia production are found in the younger stands along an age gradient of Pinus sylvestris stands [3]. Presumably, forest stands with different ages have different nutrient and water requirements, correspondingly, mycorrhizal fungi will vary with the age of the forest stands [65]. Stand productivity of forest ecosystems decreases at mature ages, consequently resulting in reduction of the demand for nutrient and water supply from fine roots and their associated mycorrhizal fungi [66]. Mycelia carbon use efficiency deceases significantly with increasing forest age by about $65 \%$ [4]. Thus, biomass allocation to belowground parts decreases with increasing stand age [67]. In mature forest ecosystems, elevated $\mathrm{N}$ input plays an additional effect on the lower carbon supply for mycorrhizal fungus growth.

Our results suggest that the incubation time of ingrowth mesh bag is an important aspect influencing the response of MFM to N addition. It is noted that a lag time, indeed, existed before mycorrhizal fungi entered ingrowth mesh bags following the insertion of bags [17]. Short-term 
experiments with ingrowth mesh bags favor fast-growers and early colonizers, which first colonize the mesh bags by many fast-growing mycelia [68], while some mycorrhizal fungi specialized on nutrient utilizing may need more time to colonize the mesh bags [69]. Additionally, priority effects favor persistence of early colonizers successfully, and prevent establishment of other mycorrhizal fungus species [70]. Thus, the length of the incubation duration largely influences the composition of mycorrhizal fungi colonized into the mesh bags. Moreover, turnover rate also influences the estimates of MFM in the ingrowth mesh bags [3,71]. Therefore, mycorrhizal fungal community colonizing ingrowth mesh bags is likely to be very different from that in natural soils using soil core methods. Therefore, these differing responses of MFM to $\mathrm{N}$ addition from ingrowth mesh bag method vs. soil core method may be due to that some species or clades are overrepresented and some others are underrepresented or even missing in the mesh bags [17]. In addition, each of the biomarkers will bring different information about the mycorrhizal fungi. For instance, chitin and ergosterol reflect the total and the living fungal biomass in ectomycorrhizas, respectively $[17,72]$. Other estimation methods of MFM (e.g., agar film) cannot determine the saprotroph hyphae [40]. Accordingly, a main issue raised is how to quantify mycorrhizal hyphae. Thus, methodological effects on responses of mycorrhizal fungal mycelium to global change factors are related with mycorrhizal fungal community assemblages [73]. Given the sets of limitations of the applied methods and techniques, the combination of several techniques in the same study is a feasible way to overcome some of the limitations [17].

\subsection{The Responses of MFM to P Addition, Organic Matter Addition, and Warming}

We observed that $\mathrm{P}$ addition significantly increased the production of MFM, suggesting a further extension of the finest part of the fine root system [74]. The positive effects of $\mathrm{P}$ addition found in this analysis seem to be quite surprising, which were not expected by our hypotheses. Several mechanisms have been proposed to elucidate the $\mathrm{P}$ effects on mycorrhizal fungi. The increased soil carbon availability through increased leaf litterfall and fine root biomass caused by relieved $\mathrm{P}$ constraints is considered to be one reason for the positive effects of $\mathrm{P}$ addition on MFM $[75,76]$. The high $\mathrm{P}$ input improves soil $\mathrm{pH}$ and osmotic potential, which may also promote the mycorrhizal fungal growth [38]. Furthermore, plants use mycorrhizal fungi for nutrient acquisition, and improved nutrient status in the host plant is also considered as a primary factor influencing carbon allocation to MFM production [77]. Here, we found the positive effects of $P$ addition significantly increased with increasing $\mathrm{N}$ content in host plant leaves. This result indicates the $\mathrm{P}$ gradually becomes a limiting factor for the growth of MFM with increasing $\mathrm{N}$ availability (higher $\mathrm{N}$ content in tree leaves). $\mathrm{P}$ addition alleviates this limitation and increases carbon input to the mycorrhizal fungi [75]. Given the tremendous discrepancy in climate, vegetation, soil types, and also P availability from tropical to boreal forest biomes in our analysis, more studies at the global scale are needed to conclude the effects of P on mycorrhizal fungi and their mycelium production. The enhanced MFM by organic matter addition is attributed to the beneficial effects of increased organic matter on water status, soil structure, $\mathrm{CO}_{2}$ pressure, and synergistic microbial activity in the soil [78]. The higher organic matter content can improve the water-holding capacity of forest soils, leading to an increase in the mycelium growth of mycorrhizal fungi [29]. The higher organic matter content can improve soil physical properties, with increasing soil aeration and decreasing mechanical resistance to the growth of MFM $[10,26]$. Mineralization of organic matter results in higher concentrations of $\mathrm{CO}_{2}$ [10], and as discussed above, elevated $\mathrm{CO}_{2}$ concentrations can enhance mycelium growth of mycorrhizal fungi. Increased microbial enzyme activities after organic matter addition indicate a specialization of the microbial communities in favor of mycorrhizal fungi [79]. The EM fungi, in turn, invest large amounts of carbon to produce a range of hydrolytic and oxidative enzymes that break down carbon-containing compounds and mobilize nutrients from soil organic matter [80].

Unexpectedly, we failed to detect a warming effect on MFM, which does not support our hypothesis that MFM responds positively to increased temperature. This result challenges the conventional view that climate warming will advance in the spring and delay in the autumn (and thus longer 
growing season length), which will have beneficial effects on mycorrhizal fungi [23,39,81]. In fact, both positive and negative effects of warming on the growth of mycorrhizal fungi have been reported $[23,82]$. The decrease in soil moisture with soil warming can probably limit mycorrhizal fungus activity, specifically in the dry season and dry areas [82]. Besides, mycorrhizal fungal community composition exhibits highly variable responses to elevated temperatures [83]. Consequently, we still have little information on the mechanisms of these different responses of MFM to climate warming, suggesting that much more attention should be paid to temperature effects on the mycorrhizal fungi in future studies.

\section{Conclusions}

Our meta-analysis demonstrates that the responses of MFM to different environmental factors depend on mycorrhizal type, mycorrhizal organization level, and experimental setting, such as duration time of treatment and sampling method. This suggests that forest nutrient and carbon cycling models should take MFM responses into account. In this meta-analysis, we also found that many other biotic and abiotic variables were not associated with effect size of environmental factors on MFM. The lack of statistically significant result does not definitely indicate that these factors do not have effects on mycorrhizal fungi, given the small number of observations or studies. Therefore, further research about the complex carbon allocation patterns between host plants and their associated mycorrhizal fungi, and a changed assemblage of mycorrhizal fungal taxa in the conditions of various global change factors covariation are urgently needed.

Author Contributions: C.W. and S.Z. conceived the ideas; C.W. and S.Z. collected the data and performed the analysis; C.W. wrote the first draft of the manuscript; M.-H.L. led the writing.

Funding: This research was funded by the Natural Science Foundation of China, grant number 41971052 and 31500354; the National Key R\&D Program of China, grant number 2019 YFA0607300 and China Postdoctoral Science Foundation, grant number 2016M601343 and 2018T110232.

Conflicts of Interest: The authors declare no conflict of interest.

\section{Appendix A The List of the Data Sources}

1. Alberton, O.; Kuyper, T.W. Ectomycorrhizal fungi associated with Pinus sylvestris seedlings respond differently to increased carbon and nitrogen availability: implications for ecosystem responses to global change. Glob. Chang. Biol. 2009, 15, 166-175, doi:10.1111/j.1365-2486.2008.01714.x.

2. Alberton, O.; Kuyper, T.W.; Gorissen, A. Competition for nitrogen between Pinus sylvestris and ectomycorrhizal fungi generates potential for negative feedback under elevated $\mathrm{CO}_{2}$. Plant Soil 2007, 296, 159-172, doi:10.1007/s11104-007-9306-5.

3. Clark, N.M.; Rillig, M.C.; Nowak, R.S. Arbuscular mycorrhizal fungal abundance in the Mojave Desert: Seasonal dynamics and impacts of elevated $\mathrm{CO}_{2}$. J. Arid Environ. 2009, 73, 834-843, doi:10.1016/j.jaridenv.2009.03.004.

4. Fortuna, P.; Avio, L.; Morini, S.; Giovannetti, M. Fungal biomass production in response to elevated atmospheric CO 2 in a Glomus mosseae-Prunus cerasifera model system. Mycol. Prog. 2012, 11, 17-26, doi:10.1007/s11557-010-0721-2.

5. Fransson, P.M.; Taylor, A.F.; Finlay, R.D. Mycelial production, spread and root colonisation by the ectomycorrhizal fungi Hebeloma crustuliniforme and Paxillus involutus under elevated atmospheric $\mathrm{CO}_{2}$. Mycorrhiza 2005, 15, 25-31, doi:10.1007/s00572-003-0289-7.

6. Fransson, P.M.; Anderson, I.C.; Alexander, I.J. Does carbon partitioning in ectomycorrhizal pine seedlings under elevated $\mathrm{CO}_{2}$ vary with fungal species? Plant Soil 2007, 291, 323-333, doi:10.1007/s11104-007-9203-y.

7. Garcia, M.O.; Ovasapyan, T.; Greas, M.; Treseder, K.K. Mycorrhizal dynamics under elevated $\mathrm{CO}_{2}$ and nitrogen fertilization in a warm temperate forest. Plant Soil 2008, 303, 301-310, doi:10.1007/s11104-007-9509-9. 
8. Ineichen, K.; Wiemken, V.; Wiemken, A. Shoots, roots and ectomycorrhiza formation of pine seedlings at elevated atmospheric carbon dioxide. Plant Cell Environ. 1995, 18, 703-707, doi:10.1111/j.1365-3040.1995.tb00572.x.

9. Kasurinen, A.; Keinänen, M.M.; Kaipainen, S.; Nilsson, L.O.; Vapaavuori, E.; Kontro, M.H.; Holopainen, T. Below-ground responses of silver birch trees exposed to elevated $\mathrm{CO}_{2}$ and $\mathrm{O}_{3}$ levels during three growing seasons. Glob. Chang. Biol. 2005, 11, 1167-1179, doi:10.1111/j.1365-2486.2005.00970.x.

10. Klamer, M.; Roberts, M.S.; Levine, L.H.; Drake, B.G.; Garland, J.L. Influence of elevated $\mathrm{CO}_{2}$ on the fungal community in a coastal scrub oak forest soil investigated with terminal-restriction fragment length polymorphism analysis. Appl. Environ. Microbiol. 2002, 68, 4370-4376, doi:10.1128/AEM.68.9.4370-4376.2002.

11. Klironomos, J.; Rillig, M.; Allen, M.; Zak, D.; Kubiske, M.; Pregitzer, K. Soil fungal-arthropod responses to Populus tremuloides grown under enriched atmospheric $\mathrm{CO}_{2}$ under field conditions. Glob. Chang. Biol. 1997, 3, 473-478, doi:10.1046/j.1365-2486.1997.00085.x.

12. Lussenhop, J.; Treonis, A.; Curtis, P.S.; Teeri, J.A.; Vogel, C.S. Response of soil biota to elevated atmospheric $\mathrm{CO}_{2}$ in poplar model systems. Oecologia 1998, 113, 247-251, doi:10.1007/s004420050375.

13. Markkola, A.M.; Ohtonen, A.; Ahonen-Jonnarth, U.; Ohtonen, R. Scots pine responses to $\mathrm{CO}_{2}$ enrichment-I. Ectomycorrhizal fungi and soil fauna. Environ. Pollut. 1996, 94, 309-316, doi:10.1016/S0269-7491(96)00090-5.

14. Parrent, J.L.; Vilgalys, R. Biomass and compositional responses of ectomycorrhizal fungal hyphae to elevated $\mathrm{CO}_{2}$ and nitrogen fertilization. New Phytol. 2007, 176, 164-174, doi:10.1111/j.1469-8137.2007.02155.x.

15. Rillig, M.C.; Allen, M.F. Arbuscular mycorrhizae of Gutierrezia sarothrae and elevated carbon dioxide: evidence for shifts in C allocation to and within the mycobiont. Soil Biol. Biochem. 1998, 30, 2001-2008, doi:10.1016/S0038-0717(98)00073-X.

16. Rouhier, H.; Read, D. Plant and fungal responses to elevated atmospheric carbon dioxide in mycorrhizal seedlings of Pinus sylvestris. Environ. Exp. Bot. 1998, 40, 237-246, doi:10.1016/S0098-8472(98)00039-2.

17. Rouhier, H.; Read, D.J. Plant and fungal responses to elevated atmospheric $\mathrm{CO}_{2}$ in mycorrhizal seedlings of Betula pendula. Environ. Exp. Bot. 1999, 42, 231-241, doi:10.1016/S0098-8472(99)00039-8.

18. Weigt, R.B.; Raidl, S.; Verma, R.; Rodenkirchen, H.; Göttlein, A.; Agerer, R. Effects of twice-ambient carbon dioxide and nitrogen amendment on biomass, nutrient contents and carbon costs of Norway spruce seedlings as influenced by mycorrhization with Piloderma croceum and Tomentellopsis submollis. Mycorrhiza 2011, 21, 375-391, doi:10.1007/s00572-010-0343-1.

19. Wiemken, V.; Ineichen, K.; Boller, T. Development of ectomycorrhizas in model beech-spruce ecosystems on siliceous and calcareous soil: a 4-year experiment with atmospheric $\mathrm{CO}_{2}$ enrichment and nitrogen fertilization. Plant Soil 2001, 234, 99-108, doi:10.1023/A:1010500400263.

20. Hagerberg, D.; Thelin, G.; Wallander, H. The production of ectomycorrhizal mycelium in forests: relation between forest nutrient status and local mineral sources. Plant Soil 2003, 252, 279-290.

21. Potila, H.; Wallander, H.; Sarjala, T. Growth of ectomycorrhizal fungi in drained peatland forests with variable P and K availability. Plant Soil 2009, 316, 139-150, doi:10.1007/s11104-008-9766-2.

22. Bahr, A.; Ellström, M.; Bergh, J.; Wallander, H. Nitrogen leaching and ectomycorrhizal nitrogen retention capacity in a Norway spruce forest fertilized with nitrogen and phosphorus. Plant Soil 2015, 390, 323-335, doi:10.1007/s11104-015-2408-6.

23. Ekblad, A.; Mikusinska, A.; Ågren, G.I.; Menichetti, L.; Wallander, H.; Vilgalys, R.; Bahr, A.; Eriksson, U. Production and turnover of ectomycorrhizal extramatrical mycelial biomass and 
necromass under elevated $\mathrm{CO}_{2}$ and nitrogen fertilization. New Phytol. 2016, 211, 874-885, doi:10.1111/nph.13961.

24. Hendricks, J.J.; Mitchell, R.J.; Kuehn, K.A.; Pecot, S.D.; Sims, S.E. Measuring external mycelia production of ectomycorrhizal fungi in the field: the soil matrix matters. New Phytol. 2006, $171,179-186$.

25. Hendricks, J.J.; Mitchell, R.J.; Kuehn, K.A.; Pecot, S.D. Ectomycorrhizal fungal mycelia turnover in a longleaf pine forest. New Phytol. 2016, 209, 1693-1704.

26. Kårén, O.; Nylund, J.-E. Effects of ammonium sulphate on the community structure and biomass of ectomycorrhizal fungi in a Norway spruce stand in southwestern Sweden. Can. J. Bot. 1997, $75,1628-1642$.

27. Leppälammi-Kujansuu, J.; Ostonen, I.; Strömgren, M.; Nilsson, L.O.; Kleja, D.; Sah, S.; Helmisaari, H.-S. Effects of long-term temperature and nutrient manipulation on Norway spruce fine roots and mycelia production. Plant soil 2013, 366, 287-303, doi:10.1007/s11104-012-1431-0.

28. Li, Y.J.; Zhu, L.Y.; Yin, H.J.; Liu, Q.; Jiang, X.M.; Zhao, C.Z. Effects of 3-year continuous night-time warming and nitrogen fertilization on ectomycorrhizae of Picea asperata and the ectomycorrhizal fungal diversity. Acta Ecol. Sin. 2015, 35, 2967-2977, doi:10.5846/stxb201308292172. (In Chinese with English Abstract)

29. Li, L.; McCormack, M.L.; Chen, F.; Wang, H.; Ma, Z.; Guo, D. Different responses of absorptive roots and arbuscular mycorrhizal fungi to fertilization provide diverse nutrient acquisition strategies in Chinese fir. For. Ecol. Manag. 2019, 433, 64-72.

30. Mayor, J.R.; Mack, M.C.; Schuur, E.A. Decoupled stoichiometric, isotopic, and fungal responses of an ectomycorrhizal black spruce forest to nitrogen and phosphorus additions. Soil Biol. Biochem. 2015, 88, 247-256, doi:10.1016/j.soilbio.2015.05.028.

31. Nilsson, L.O.; Wallander, H. Production of external mycelium by ectomycorrhizal fungi in a Norway spruce forest was reduced in response to nitrogen fertilization. New Phyto. 2003, 158, 409-416, doi:10.1046/j.1469-8137.2003.00728.x.

32. Sims, S.E.; Hendricks, J.J.; Mitchell, R.J.; Kuehn, K.A.; Pecot, S.D. Nitrogen decreases and precipitation increases ectomycorrhizal extramatrical mycelia production in a longleaf pine forest. Mycorrhiza 2007, 17, 299-309.

33. Treseder, K.K.; Allen, M.F. Direct nitrogen and phosphorus limitation of arbuscular mycorrhizal fungi: a model and field test. New Phytol. 2002, 155, 507-515, doi:10.1046/j.1469-8137.2002.00470.x.

34. van Diepen, L.T.; Lilleskov, E.A.; Pregitzer, K.S.; Miller, R.M. Simulated nitrogen deposition causes a decline of intra-and extraradical abundance of arbuscular mycorrhizal fungi and changes in microbial community structure in northern hardwood forests. Ecosystems 2010, 13, 683-695, doi:10.1007/s10021-010-9347-0.

35. Wallander, H.; Nylund, J.E. Effects of excess nitrogen and phosphorus starvation on the extramatrical mycelium of ectomycorrhizas of Pinus sylvestris L. New Phytol. 1992, 120, 495-503.

36. Wallander, H.; Ekblad, A.; Bergh, J. Growth and carbon sequestration by ectomycorrhizal fungi in intensively fertilized Norway spruce forests. For. Ecol. Manag. 2011, 262, 999-1007, doi:10.1016/j.foreco.2011.05.035.

37. Cheng, L.; Chen, W.; Adams, T.S.; Wei, X.; Li, L.; McCormack, M.L.; DeForest, J.L.; Koide, R.T.; Eissenstat, D.M. Mycorrhizal fungi and roots are complementary in foraging within nutrient patches. Ecology 2016, 97, 2815-2823.

38. Clemmensen, K.E.; Michelsen, A.; Jonasson, S.; Shaver, G.R. Increased ectomycorrhizal fungal abundance after long-term fertilization and warming of two arctic tundra ecosystems. New Phytol. 2006, 171, 391-404, doi:10.1111/j.1469-8137.2006.01778.x.

39. Olsson, P.A.; Wilhelmsson, P. The growth of external AM fungal mycelium in sand dunes and in experimental systems. Plant Soil 2000, 226, 161-169, doi:10.1023/A:1026565314345. 
40. Liu, B.; Li, H.; Zhu, B.; Koide, R.T.; Eissenstat, D.M.; Guo, D. Complementarity in nutrient foraging strategies of absorptive fine roots and arbuscular mycorrhizal fungi across 14 coexisting subtropical tree species. New Phytol. 2015, 208, 125-136, doi:10.1111/nph.13434.

41. Hammer, E.C.; Nasr, H.; Wallander, H. Effects of different organic materials and mineral nutrients on arbuscular mycorrhizal fungal growth in a Mediterranean saline dryland. Soil Biol. Biochem. 2011, 43, 2332-2337, doi:10.1016/j.soilbio.2011.07.004.

42. Labidi, S.; Nasr, H.; Zouaghi, M.; Wallander, H. Effects of compost addition on extra-radical growth of arbuscular mycorrhizal fungi in Acacia tortilis ssp. raddiana savanna in a pre-Saharan area. Appl. Soil Ecol. 2007, 35, 184-192, doi:10.1016/j.apsoil.2006.04.009.

43. Chen, W.; Koide, R.T.; Adams, T.S.; DeForest, J.L.; Cheng, L.; Eissenstat, D.M. Root morphology and mycorrhizal symbioses together shape nutrient foraging strategies of temperate trees. Proc. Natl. Acad. Sci. USA 2016, 113, 8741-8746, doi:10.1073/pnas.1601006113.

44. Vaidya, G.S.; Shrestha, K.; Khadge, B.R.; Johnson, N.C.; Wallander, H. Organic matter stimulates bacteria and arbuscular mycorrhizal fungi in Bauhinia purpurea and Leucaena diversifolia plantations on eroded slopes in Nepal. Restor. Ecol. 2008, 16, 79-87, doi:10.1111/j.1526-100X.2007.00264.x.

45. Hagerberg, D.; Wallander, H. The impact of forest residue removal and wood ash amendment on the growth of the ectomycorrhizal external mycelium. FEMS Microbiol. Ecol. 2002, 39, 139-146.

46. Majdi, H.; Truus, L.; Johansson, U.; Nylund, J.-E.; Wallander, H. Effects of slash retention and wood ash addition on fine root biomass and production and fungal mycelium in a Norway spruce stand in SW Sweden. For. Ecol. Manag. 2008, 255, 2109-2117.

\section{References}

1. Smith, S.E.; Read, D.J. Mycorrhizal Symbiosis; Academic Press: London, UK, 2008.

2. Averill, C.; Turner, B.L.; Finzi, A.C. Mycorrhiza-mediated competition between plants and decomposers drives soil carbon storage. Nature 2014, 505, 543-545. [CrossRef] [PubMed]

3. Hagenbo, A.; Clemmensen, K.E.; Finlay, R.D.; Kyaschenko, J.; Lindahl, B.D.; Fransson, P.; Ekblad, A. Changes in turnover rather than production regulate biomass of ectomycorrhizal fungal mycelium across a Pinus sylvestris chronosequence. New Phytol. 2017, 214, 424-431. [CrossRef] [PubMed]

4. Hagenbo, A.; Hadden, D.; Clemmensen, K.E.; Grelle, A.; Manzoni, S.; Mölder, M.; Ekblad, A.; Fransson, P. Carbon use efficiency of mycorrhizal fungal mycelium increases during the growing season but decreases with forest age across a Pinus sylvestris chronosequence. J. Ecol. 2019, 107, 2808-2822. [CrossRef]

5. Hagerberg, D.; Thelin, G.; Wallander, H. The production of ectomycorrhizal mycelium in forests: Relation between forest nutrient status and local mineral sources. Plant Soil 2003, 252, 279-290. [CrossRef]

6. Sims, S.E.; Hendricks, J.J.; Mitchell, R.J.; Kuehn, K.A.; Pecot, S.D. Nitrogen decreases and precipitation increases ectomycorrhizal extramatrical mycelia production in a longleaf pine forest. Mycorrhiza 2007, 17, 299-309. [CrossRef]

7. Majdi, H.; Truus, L.; Johansson, U.; Nylund, J.-E.; Wallander, H. Effects of slash retention and wood ash addition on fine root biomass and production and fungal mycelium in a Norway spruce stand in SW Sweden. For. Ecol. Manag. 2008, 255, 2109-2117. [CrossRef]

8. Rouhier, H.; Read, D.J. Plant and fungal responses to elevated atmospheric $\mathrm{CO}_{2}$ in mycorrhizal seedlings of Betula pendula. Environ. Exp. Bot. 1999, 42, 231-241. [CrossRef]

9. Rousseau, J.; Sylvia, D.; Fox, A. Contribution of ectomycorrhiza to the potential nutrient-absorbing surface of pine. New Phytol. 1994, 128, 639-644. [CrossRef]

10. Joner, E.J.; Jakobsen, I. Growth and extracellular phosphatase activity of arbuscular mycorrhizal hyphae as influenced by soil organic matter. Soil Biol. Biochem. 1995, 27, 1153-1159. [CrossRef]

11. Bahr, A.; Ellström, M.; Bergh, J.; Wallander, H. Nitrogen leaching and ectomycorrhizal nitrogen retention capacity in a Norway spruce forest fertilized with nitrogen and phosphorus. Plant Soil 2015, 390, 323-335. [CrossRef]

12. Simard, S.W.; Jones, M.D.; Durall, D.M. Carbon and nutrient fluxes within and between mycorrhizal plants. In Mycorrhizal Ecology; van der Heijden, M., Sander, I., Eds.; Springer: Berlin/Heidelberg, Germany, 2003; pp. 33-74. 
13. Wallander, H.; Ekblad, A.; Bergh, J. Growth and carbon sequestration by ectomycorrhizal fungi in intensively fertilized Norway spruce forests. For. Ecol. Manag. 2011, 262, 999-1007. [CrossRef]

14. Godbold, D.L.; Hoosbeek, M.R.; Lukac, M.; Cotrufo, M.F.; Janssens, I.A.; Ceulemans, R.; Polle, A.; Velthorst, E.J.; Scarascia-Mugnozza, G.; De Angelis, P.; et al. Mycorrhizal hyphal turnover as a dominant process for carbon input into soil organic matter. Plant Soil 2006, 281, 15-24. [CrossRef]

15. Clemmensen, K.E.; Bahr, A.; Ovaskainen, O.; Dahlberg, A.; Ekblad, A.; Wallander, H.; Stenlid, J.; Finlay, R.D.; Wardle, D.A.; Lindahl, B.D. Roots and associated fungi drive long-term carbon sequestration. Science 2013, 339, 1615-1618. [CrossRef] [PubMed]

16. Fransson, P.M.A.; Taylor, A.F.S.; Finlay, R.D. Mycelial production, spread and root colonisation by the ectomycorrhizal fungi Hebeloma crustuliniforme and Paxillus involutus under elevated atmospheric $\mathrm{CO}_{2}$. Mycorrhiza 2005, 15, 25-31. [CrossRef]

17. Wallander, H.; Ekblad, A.; Godbold, D.; Johnson, D.; Bahr, A.; Baldrian, P.; Björk, R.; Kieliszewska-Rokicka, B.; Kjøller, R.; Kraigher, H. Evaluation of methods to estimate production, biomass and turnover of ectomycorrhizal mycelium in forests soils-A review. Soil Biol. Biochem. 2013, 57, 1034-1047. [CrossRef]

18. Mohan, J.E.; Cowden, C.C.; Baas, P.; Dawadi, A.; Frankson, P.T.; Helmick, K.; Hughes, E.; Khan, S.; Lang, A.; Machmuller, M.; et al. Mycorrhizal fungi mediation of terrestrial ecosystem responses to global change: Mini-review. Fungal Ecol. 2014, 10, 3-19. [CrossRef]

19. Ekblad, A.; Wallander, H.; Godbold, D.; Cruz, C.; Johnson, D.; Baldrian, P.; Björk, R.; Epron, D.; Kieliszewska-Rokicka, B.; Kjøller, R. The production and turnover of extramatrical mycelium of ectomycorrhizal fungi in forest soils: Role in carbon cycling. Plant Soil 2013, 366, 1-27. [CrossRef]

20. Beyene, T.; Lettenmaier, D.P.; Kabat, P. Hydrologic impacts of climate change on the Nile River Basin: Implications of the 2007 IPCC scenarios. Clim. Chang. 2010, 100, 433-461. [CrossRef]

21. Parrent, J.L.; Vilgalys, R. Biomass and compositional responses of ectomycorrhizal fungal hyphae to elevated $\mathrm{CO}_{2}$ and nitrogen fertilization. New Phytol. 2007, 176, 164-174. [CrossRef]

22. Soudzilovskaia, N.A.; Douma, J.C.; Akhmetzhanova, A.A.; van Bodegom, P.M.; Cornwell, W.K.; Moens, E.J.; Treseder, K.K.; Tibbett, M.; Wang, Y.-P.; Cornelissen, J.H.C. Global patterns of plant root colonization intensity by mycorrhizal fungi explained by climate and soil chemistry. Glob. Ecol. Biogeogr. 2015, 24, 371-382. [CrossRef]

23. Leppälammi-Kujansuu, J.; Ostonen, I.; Strömgren, M.; Nilsson, L.O.; Kleja, D.B.; Sah, S.P.; Helmisaari, H.S. Effects of long-term temperature and nutrient manipulation on Norway spruce fine roots and mycelia production. Plant Soil 2013, 366, 287-303. [CrossRef]

24. Bryanin, S.V.; Makoto, K. Fire-derived charcoal affects fine root vitality in a post-fire Gmelin larch forest: Field evidence. Plant Soil 2017, 416, 409-418. [CrossRef]

25. Sun, H.; Santalahti, M.; Pumpanen, J.; Köster, K.; Berninger, F.; Raffaello, T.; Jumpponen, A.; Asiegbu, F.O.; Heinonsalo, J. Fungal community shifts in structure and function across a boreal forest fire chronosequence. Appl. Environ. Microbiol. 2015, 81, 7869-7880. [CrossRef] [PubMed]

26. Hammer, E.C.; Nasr, H.; Wallander, H. Effects of different organic materials and mineral nutrients on arbuscular mycorrhizal fungal growth in a Mediterranean saline dryland. Soil Biol. Biochem. 2011, 43, 2332-2337. [CrossRef]

27. Mahmood, S.; Finlay, R.D.; Erland, S.; Wallander, H. Solubilisation and colonisation of wood ash by ectomycorrhizal fungi isolated from a wood ash fertilised spruce forest. FEMS Microbiol. Ecol. 2001, 35, 151-161. [CrossRef] [PubMed]

28. Hagerberg, D.; Wallander, H. The impact of forest residue removal and wood ash amendment on the growth of the ectomycorrhizal external mycelium. FEMS Microbiol. Ecol. 2002, 39, 139-146. [CrossRef] [PubMed]

29. Labidi, S.; Nasr, H.; Zouaghi, M.; Wallander, H. Effects of compost addition on extra-radical growth of arbuscular mycorrhizal fungi in Acacia tortilis ssp. raddiana savanna in a pre-Saharan area. Appl. Soil Ecol. 2007, 35, 184-192. [CrossRef]

30. Vallack, H.; Leronni, V.; Metcalfe, D.; Högberg, P.; Ineson, P.; Subke, J.-A. Application of nitrogen fertilizer to a boreal pine forest has a negative impact on the respiration of ectomycorrhizal hyphae. Plant Soil 2012, 352, 405-417. [CrossRef]

31. Nillson, L.O.; Wallander, H. Production of external mycelium by ectomycorrhizal fungi in a Norway spruce forest was reduced in response to nitrogen fertilization. New Phytol. 2003, 158, 409-416. [CrossRef] 
32. Johnson, N.C. Resource stoichiometry elucidates the structure and function of arbuscular mycorrhizas across scales. New Phytol. 2010, 185, 631-647. [CrossRef]

33. Lin, G.G.; McCormack, M.L.; Guo, D.L. Similar soil carbon sequestration potential but contrasting mode of nitrogen cycling between arbuscular mycorrhizal and ectomycorrhizal forests. New Phytol. 2017, 213, 1440-1451. [CrossRef] [PubMed]

34. Terrer, C.; Vicca, S.; Hungate, B.A.; Phillips, R.P.; Prentice, I.C. Mycorrhizal association as a primary control of the $\mathrm{CO}_{2}$ fertilization effect. Science 2016, 353, 72-74. [CrossRef]

35. Dong, Y.; Wang, Z.; Sun, H.; Yang, W.; Xu, H. The response patterns of arbuscular mycorrhizal and ectomycorrhizal symbionts under elevated $\mathrm{CO}_{2}$ : A meta-analysis. Front. Microbiol. 2018, 9, 1248. [CrossRef] [PubMed]

36. de Miranda, J.C.C.; Harris, P.J. The effect of soil phosphorus on the external mycelium growth of arbuscular mycorrhizal fungi during the early stages of mycorrhiza formation. Plant Soil 1994, 166, 271-280. [CrossRef]

37. Mayor, J.R.; Mack, M.C.; Schuur, E.A. Decoupled stoichiometric, isotopic, and fungal responses of an ectomycorrhizal black spruce forest to nitrogen and phosphorus additions. Soil Biol. Biochem. 2015, 88, 247-256. [CrossRef]

38. Huang, J.; Hu, B.; Qi, K.; Chen, W.; Pang, X.; Bao, W.; Tian, G. Effects of phosphorus addition on soil microbial biomass and community composition in a subalpine spruce plantation. Eur. J. Soil Biol. 2016, 72, 35-41. [CrossRef]

39. Clemmensen, K.E.; Michelsen, A.; Jonasson, S.; Shaver, G.R. Increased ectomycorrhizal fungal abundance after long-term fertilization and warming of two arctic tundra ecosystems. New Phytol. 2006, 171, 391-404. [CrossRef] [PubMed]

40. Weigt, R.B.; Raidl, S.; Verma, R.; Rodenkirchen, H.; Göttlein, A.; Agerer, R. Effects of twice-ambient carbon dioxide and nitrogen amendment on biomass, nutrient contents and carbon costs of Norway spruce seedlings as influenced by mycorrhization with Piloderma croceum and Tomentellopsis submollis. Mycorrhiza 2011, 21, 375-391. [CrossRef]

41. Treseder, K.K. A meta-analysis of mycorrhizal responses to nitrogen, phosphorus, and atmospheric $\mathrm{CO}_{2}$ in field studies. New Phytol. 2004, 164, 347-355. [CrossRef]

42. Hedges, L.V.; Gurevitch, J.; Curtis, P.S. The meta-analysis of response ratios in experimental ecology. Ecology 1999, 80, 1150-1156. [CrossRef]

43. van Groenigen, K.J.; Osenberg, C.W.; Hungate, B.A. Increased soil emissions of potent greenhouse gases under increased atmospheric $\mathrm{CO}_{2}$. Nature 2011, 475, 214-216. [CrossRef] [PubMed]

44. Senior, A.M.; Grueber, C.E.; Kamiya, T.; Lagisz, M.; O’Dwyer, K.; Santos, E.S.A.; Nakagawa, S. Heterogeneity in ecological and evolutionary meta-analyses: Its magnitude and implications. Ecology 2016, 97, 3293-3299. [CrossRef] [PubMed]

45. Rossetti, M.R.; Tscharntke, T.; Aguilar, R.; Batáry, P. Responses of insect herbivores and herbivory to habitat fragmentation: A hierarchical meta-analysis. Ecol. Lett. 2017, 20, 264-272. [CrossRef] [PubMed]

46. Tedersoo, L.; Mett, M.; Ishida, T.A.; Bahram, M. Phylogenetic relationships among host plants explain differences in fungal species richness and community composition in ectomycorrhizal symbiosis. New Phytol. 2013, 199, 822-831. [CrossRef] [PubMed]

47. Zanne, A.E.; Tank, D.C.; Cornwell, W.K.; Eastman, J.M.; Smith, S.A.; FitzJohn, R.G.; McGlinn, D.J.; O'Meara, B.C.; Moles, A.T.; Reich, P.B.; et al. Three keys to the radiation of angiosperms into freezing environments. Nature 2014, 506, 89-92. [CrossRef] [PubMed]

48. Liu, Y.; Oduor, A.M.O.; Zhang, Z.; Manea, A.; Tooth, I.M.; Leishman, M.R.; Xu, X.; van Kleunen, M. Do invasive alien plants benefit more from global environmental change than native plants? Glob. Chang. Biol. 2017, 23, 3363-3370. [CrossRef] [PubMed]

49. Alberton, O.; Kuyper, T.W.; Gorissen, A. Taking mycocentrism seriously: Mycorrhizal fungal and plant responses to elevated $\mathrm{CO}_{2}$. New Phytol. 2005, 167, 859-868. [CrossRef]

50. Wiemken, V.; Ineichen, K.; Boller, T. Development of ectomycorrhizas in model beech-spruce ecosystems on siliceous and calcareous soil: A 4-year experiment with atmospheric $\mathrm{CO}_{2}$ enrichment and nitrogen fertilization. Plant Soil 2001, 234, 99-108. [CrossRef]

51. Cairney, J.W.G. Extramatrical mycelia of ectomycorrhizal fungi as moderators of carbon dynamics in forest soil. Soil Biol. Biochem. 2012, 47, 198-208. [CrossRef] 
52. Pickles, B.J.; Egger, K.N.; Massicotte, H.B.; Green, D.S. Ectomycorrhizas and climate change. Fungal Ecol. 2012, 5, 73-84. [CrossRef]

53. Johnson, D.W. Progressive N limitation in forests: Review and implications for long-term responses to elevated $\mathrm{CO}_{2}$. Ecology 2006, 87, 64-75. [CrossRef] [PubMed]

54. Gehring, C.A.; Mueller, R.C.; Whitham, T.G. Environmental and genetic effects on the formation of ectomycorrhizal and arbuscular mycorrhizal associations in cottonwoods. Oecologia 2006, 149, 158-164. [CrossRef] [PubMed]

55. Soudzilovskaia, N.A.; van der Heijden, M.G.A.; Cornelissen, J.H.C.; Makarov, M.I.; Onipchenko, V.G.; Maslov, M.N.; Akhmetzhanova, A.A.; van Bodegom, P.M. Quantitative assessment of the differential impacts of arbuscular and ectomycorrhiza on soil carbon cycling. New Phytol. 2015, 208, 280-293. [CrossRef] [PubMed]

56. O'Neill, E.G. Responses of soil biota to elevated atmospheric carbon dioxide. Plant Soil 1994, 165, 55-65. [CrossRef]

57. Lilleskov, E.; Hobbie, E.; Horton, T. Conservation of ectomycorrhizal fungi: Exploring the linkages between functional and taxonomic responses to anthropogenic $\mathrm{N}$ deposition. Fungal Ecol. 2011, 4, 174-183. [CrossRef]

58. Wallander, H. A new hypothesis to explain allocation of dry matter between mycorrhizal fungi and pine seedlings in relation to nutrient supply. In Nutrient Uptake and Cycling in Forest Ecosystems, Proceedings of the CEC/IUFRO Symposium Nutrient Uptake and Cycling in Forest Ecosystems, Halmstad, Sweden, 7-10 June 1993; Nilsson, L.O., Hüttl, R.F., Johansson, U.T., Eds.; Springer: Dordrecht, The Netherlands, 1995; pp. 243-248. [CrossRef]

59. Bahr, A.; Ellström, M.; Akselsson, C.; Ekblad, A.; Mikusinska, A.; Wallander, H. Growth of ectomycorrhizal fungal mycelium along a Norway spruce forest nitrogen deposition gradient and its effect on nitrogen leakage. Soil Biol. Biochem. 2013, 59, 38-48. [CrossRef]

60. Sterkenburg, E.; Bahr, A.; Brandström Durling, M.; Clemmensen, K.E.; Lindahl, B.D. Changes in fungal communities along a boreal forest soil fertility gradient. New Phytol. 2015, 207, 1145-1158. [CrossRef]

61. Greaver, T.; Clark, C.; Compton, J.; Vallano, D.; Talhelm, A.; Weaver, C.; Band, L.; Baron, J.S.; Davidson, E.; Tague, C. Key ecological responses to nitrogen are altered by climate change. Nat. Clim. Chang. 2016, 6, 836-843. [CrossRef]

62. Castaño, C.; Alday, J.G.; Parladé, J.; Pera, J.; de Aragón, J.M.; Bonet, J.A. Seasonal dynamics of the ectomycorrhizal fungus Lactarius vinosus are altered by changes in soil moisture and temperature. Soil Biol. Biochem. 2017, 115, 253-260. [CrossRef]

63. Wurzburger, N.; Wright, S.J. Fine-root responses to fertilization reveal multiple nutrient limitation in a lowland tropical forest. Ecology 2015, 96, 2137-2146. [CrossRef]

64. Rosenvald, K.; Ostonen, I.; Uri, V.; Varik, M.; Tedersoo, L.; Lõhmus, K. Tree age effect on fine-root and leaf morphology in a silver birch forest chronosequence. Eur. J. For. Res. 2013, 132, 219-230. [CrossRef]

65. Børja, I.; De Wit, H.A.; Steffenrem, A.; Majdi, H. Stand age and fine root biomass, distribution and morphology in a Norway spruce chronosequence in southeast Norway. Tree Physiol. 2008, 28, 773-784. [CrossRef] [PubMed]

66. Gower, S.T.; McMurtrie, R.E.; Murty, D. Aboveground net primary production decline with stand age: Potential causes. Trends Ecol. Evol. 1996, 11, 378-382. [CrossRef]

67. Jagodzinski, A.M.; Ziolkowski, J.; Warnkowska, A.; Prais, H. Tree age effects on fine root biomass and morphology over chronosequences of Fagus sylvatica, Quercus robur and Alnus glutinosa Stands. PLoS ONE 2016, 11, e0148668. [CrossRef] [PubMed]

68. Korkama, T.; Fritze, H.; Pakkanen, A.; Pennanen, T. Interactions between extraradical ectomycorrhizal mycelia, microbes associated with the mycelia and growth rate of Norway spruce (Picea abies) clones. New Phytol. 2007, 173, 798-807. [CrossRef] [PubMed]

69. Berner, C.; Johansson, T.; Wallander, H. Long-term effect of apatite on ectomycorrhizal growth and community structure. Mycorrhiza 2012, 22, 615-621. [CrossRef]

70. Kennedy, P.G.; Peay, K.G.; Bruns, T.D. Root tip competition among ectomycorrhizal fungi: Are priority effects a rule or an exception? Ecology 2009, 90, 2098-2107. [CrossRef]

71. Potila, H.; Wallander, H.; Sarjala, T. Growth of ectomycorrhizal fungi in drained peatland forests with variable P and K availability. Plant Soil 2009, 316, 139-150. [CrossRef] 
72. Ekblad, A.; Wallander, H.; Nasholm, T. Chitin and ergosterol combined to measure total and living fungal biomass in ectomycorrhizas. New Phytol. 1998, 138, 143-149. [CrossRef]

73. Li, L.; McCormack, M.L.; Chen, F.; Wang, H.; Ma, Z.; Guo, D. Different responses of absorptive roots and arbuscular mycorrhizal fungi to fertilization provide diverse nutrient acquisition strategies in Chinese fir. For. Ecol. Manag. 2019, 433, 64-72. [CrossRef]

74. Bakker, M.; Jolicoeur, E.; Trichet, P.; Augusto, L.; Plassard, C.; Guinberteau, J.; Loustau, D. Adaptation of fine roots to annual fertilization and irrigation in a 13-year-old Pinus pinaster stand. Tree Physiol. 2009, 29, 229-238. [CrossRef] [PubMed]

75. Liu, L.; Gundersen, P.; Zhang, T.; Mo, J. Effects of phosphorus addition on soil microbial biomass and community composition in three forest types in tropical China. Soil Biol. Biochem. 2012, 44, 31-38. [CrossRef]

76. Li, J.; Li, Z.; Wang, F.; Zou, B.; Chen, Y.; Zhao, J.; Mo, Q.; Li, Y.; Li, X.; Xia, H. Effects of nitrogen and phosphorus addition on soil microbial community in a secondary tropical forest of China. Biol. Fertil. Soils 2015, 51, 207-215. [CrossRef]

77. Wallander, H.; Thelin, G. The stimulating effect of apatite on ectomycorrhizal growth diminishes after PK fertilization. Soil Biol. Biochem. 2008, 40, 2517-2522. [CrossRef]

78. Ryan, M.H.; Chilvers, G.A.; Dumaresq, D.C. Colonisation of wheat by VA-mycorrhizal fungi was found to be higher on a farm managed in an organic manner than on a conventional neighbour. Plant Soil 1994, 160, 33-40. [CrossRef]

79. Guénon, R.; Day, T.A.; Velazco-Ayuso, S.; Gros, R. Mixing of Aleppo pine and Holm oak litter increases biochemical diversity and alleviates $\mathrm{N}$ limitations of microbial activity. Soil Biol. Biochem. 2017, 105, $216-226$. [CrossRef]

80. Courty, P.-E.; Buée, M.; Diedhiou, A.G.; Frey-Klett, P.; Le Tacon, F.; Rineau, F.; Turpault, M.-P.; Uroz, S.; Garbaye, J. The role of ectomycorrhizal communities in forest ecosystem processes: New perspectives and emerging concepts. Soil Biol. Biochem. 2010, 42, 679-698. [CrossRef]

81. Rustad, L.; Campbell, J.; Marion, G.; Norby, R.; Mitchell, M.; Hartley, A.; Cornelissen, J.; Gurevitch, J.; GCTE-NEWS. A meta-analysis of the response of soil respiration, net nitrogen mineralization, and aboveground plant growth to experimental ecosystem warming. Oecologia 2001, 126, 543-562. [CrossRef]

82. Wang, H.; Liu, S.; Wang, J.; Li, D.; Shi, Z.; Liu, Y.; Xu, J.; Hong, P.; Yu, H.; Zhao, Z. Contrasting responses of heterotrophic and root-dependent respiration to soil warming in a subtropical plantation. Agric. For. Meteorol. 2017, 247, 221-228. [CrossRef]

83. Fujimura, K.E.; Egger, K.N.; Henry, G.H. The effect of experimental warming on the root-associated fungal community of Salix arctica. ISME J. 2008, 2, 105-114. [CrossRef] 